\title{
Lebecetin, a C-Lectin Protein from the Venom of Macrovipera lebetina That Inhibits Platelet Aggregation and Adhesion of Cancerous Cells
}

\author{
Sameh Sarray ${ }^{a}$ Najet Srairi ${ }^{a}$ Jose Luis ${ }^{c}$ Jacques Marvaldic \\ Mohamed El Ayeb ${ }^{a}$ Naziha Marrakchia,b \\ a Laboratoire des Venins et Toxines, Institut Pasteur de Tunis, \\ bFaculté de Médecine de Tunis, Tunisie; ${ }^{\mathrm{c}}$ CNRS UPRESA 6032, \\ Faculté de Pharmacie, Laboratoire de Biochimie Cellulaire, Marseille, France
}

\section{Key Words}

Snake venom $\cdot$ C-lectin protein $\cdot$ Anti-platelet aggregation $\cdot$ Anti-agglutination protein

\begin{abstract}
A novel C-lectin protein, lebecetin, was purified and characterized from the venom of Macrovipera lebetina. It is a disulfide-linked heterodimer of 15 and $16 \mathrm{kD}$. The subunits are homologous to each other and to the other snake venom proteins of the C-type $\left(\mathrm{Ca}^{2+}\right.$ dependent) lectin superfamily. Lebecetin shows a potent inhibitory effect on whole blood and washed platelets induced by different agonists. It inhibits the agglutination of human fixed platelets in the presence of ristocetin. Lebecetin also interferes with the adhesion of IGR39 melanoma and HT29D4 adenocarcinoma cells. These two lines adhere to lebecetin used as matrix. Lebecetin is
\end{abstract}

\begin{tabular}{ll}
\hline KARGER & ( ) 2002 S. Karger AG, Basel \\
0301-0147/01/0316-0173\$17.50/0 \\
$\begin{array}{l}\text { E-Mail karger@karger.ch } \\
\text { www.karger.com }\end{array}$ & $\begin{array}{l}\text { Accessible online at: } \\
\text { www.karger.com/journals/hae }\end{array}$
\end{tabular}

also able to strongly reduce IGR39 and HT29D4 cell adhesion to fibrinogen and laminin, but not to fibronectin and collagen types I and IV, respectively. Adhesion properties of lebecetin may thus involve integrin receptors.

Copyright @ 92002 S. Karger AG, Basel

\section{Introduction}

Lectins are defined as nonenzymatic carbohydrate-binding proteins, common in plants including trees, and particulary seeds. They have also been found in bacteria, roe, snails, vertebrates and mushrooms [1]. C-Lectin proteins (CLPs) have also been found in the venom of snakes belonging to the families of Elapidae, Viperidae and Crotalidae [2-4]. These proteins show an $\mathrm{M}_{\mathrm{r}}$ of $30,000 \mathrm{D}$ and exist as heterodimers linked by a single inter-
Dr. Sarray Sameh
Laboratoire des Venins et Toxines, Institut Pasteur de Tunis
13, Place Pasteur, BP 74, 1002 Tunis-Belvédère (Tunisia)
Tel. +216 71843755 , Fax +216 71791833
E-Mail sameh_sarray@voila.fr 
chain disulfide bond. They share a structural homology of 30-70\%. However, this group of $\mathrm{Ca}^{2+}$-dependent lectin-related proteins exhibits different effects on blood coagulation and platelet aggregation. Several CLPs induce various effects on platelet functions by modulating the interactions between von Willebrand factor (vWF) and platelet GPIb. For example, botrocetin from Bothrops jararaca venom, binds to vWF and forms an activated complex that induces platelet agglutination [5]. Alboaggregins (A and B) from Trimeresurus albolabris venom [6, 7], echicetin from Echis carinatus venom [8] and agkicetin from $A g$ kistrodon acutus venom [9] all bind to platelet GPIb and function as receptor blockers for vWF binding. However, alboaggregins induce platelet agglutination whereas echicetin and agkicetin inhibit platelet agglutination.

Lectin-like proteins were present in the venom of M. lebetina, mainly as dimeric proteins. A novel CLP, designated lebecetin, was isolated from Macrovipera lebetina venom and characterized as a potent platelet aggregation inhibitor with interesting adhesive properties.

\section{Materials and Methods}

\section{Purification of Lebecetin}

$M$. lebetina venom was dissolved in $0.2 \mathrm{M}$ ammonium acetate (pH 6.8) and applied to a Sephadex G-75 column equilibrated with the same buffer. The fractions containing the main of antiplatelet activity were collected and then loaded on a cation exchange Mono $\mathrm{S}$ (HR5/5) column previously equilibrated with $50 \mathrm{~m} M \mathrm{HEPES} / \mathrm{HCl}, \mathrm{pH} 7.5$, and eluated with a linear $\mathrm{NaCl}(0-1 M)$ gradient. RP-HPLC (C8 column) was then used to purify the protein.

\section{Amino Acid Sequence Analysis}

Lebecetin was reduced and alkylated and separated into two subunits by RP-HPLC on a C8 column. The $\mathrm{N}$-terminal sequence of each subunit was analyzed by automated Edman degradation (Model 476A, Applied Biosystem).

\section{Platelet Aggregation Assay}

Platelet-rich plasma (PRP) was prepared from rabbit blood by mixing whole blood with 0.1 vol of 3.8 of trisodium citrate followed by centrifugation at room temperature [10]. Platelet aggregation studies were carried out with a Chronolog aggregometer using $0.3 \mathrm{ml}$ of PRP at $37^{\circ} \mathrm{C}$.

Platelets were isolated from human or rabbit blood using $5 \mathrm{~m} M$ EDTA as anticoagulant. Platelets were then separated from blood and washed twice with calcium-free Tyrode's buffer, $\mathrm{pH}$ 6.5, containing $0.1 \%$ glucose, $0.25 \%$ gelatin, $2 \mathrm{mM} \mathrm{MgCl} 2$ and $0.2 \mathrm{mM}$ EGTA as previously described [11]. The final suspension was made in a modified Tyrode's buffer without EGTA, pH 7.4. Platelet aggregation was monitored at $37^{\circ} \mathrm{C}$ under stirring $(1,100 \mathrm{rpm})$ in a Chronolog aggregometer. Platelets $\left(3 \cdot 10^{8}\right.$ cells $\left./ \mathrm{ml}\right)$ were incubated for 2 min with $2 \mathrm{mM} \mathrm{CaCl}$ in the aggregometer cuvette in the presence of lebecetin before the addition of agonists.

\section{Preparation of Formalin-Fixed Platelets}

Fixed human platelets were prepared as previously described [12]. They were incubated with $2 \%$ of formalin in Tris-saline buffer overnight at $4^{\circ} \mathrm{C}$. Finally, they were washed twice with Tris-saline buffer. The final platelet pellets were suspended in an equal volume of Tris-saline buffer containing BSA $(20 \mathrm{mg} / \mathrm{ml})$.

The agglutination of fixed washed platelets induced by bovine vWF was measured using an aggregometer as previously described [11].

\section{Cell Adhesion Assay}

Flat bottom 96-well microtiter plates were coated for $2 \mathrm{~h}$ at $37^{\circ} \mathrm{C}$ with $50 \mu \mathrm{l}$ of one of the following purified extracellular matrix (ECM) proteins: fibronectin $(10 \mu \mathrm{g} / \mathrm{ml})$, vitronectin $(10 \mu \mathrm{g} / \mathrm{ml})$, laminin $(2 \mu \mathrm{g} / \mathrm{ml})$, fibrinogen $(50 \mu \mathrm{g} / \mathrm{ml})$, collagen type I $(10 \mu \mathrm{g} / \mathrm{ml})$ and collagen type IV $(10 \mu \mathrm{g} / \mathrm{ml})$. Coated wells were blocked with $1 \%$ BSA in PBS for $1 \mathrm{~h}$. The melanoma cell line IGR39 and adenocarcinoma cell line HT29D4 were routinely cultured in Dulbecco's modified Eagle's medium (DME medium) containing $4.5 \mathrm{~g} / 1$ glucose and $10 \%$ fetal calf serum in a humidified atmosphere of $5 \%$ $\mathrm{CO}_{2}$. Cells were harvested in single cell suspensions by treatment with $0.53 \mathrm{~m} M$ EDTA in PBS, washed twice with DME medium containing 0.2\% BSA (adhesion buffer) and resuspended in the same medium in the presence of lebecetin. After incubation for $30 \mathrm{~min}$ at room temperature, cells were added to coated wells in a volume of $50 \mu \mathrm{l}\left(10^{6} \mathrm{cells} / \mathrm{ml}\right)$ and allowed to adhere to the substrate for $1 \mathrm{~h}$ in a cell culture incubator. Unattached cells were removed by gently washing three 
times with adhesion buffer. Residual attached cells were fixed by $1 \%$ glutaraldehyde, stained by $0.1 \%$ crystal violet and lysed with $1 \%$ SDS. The absorbance was measured at $600 \mathrm{~nm}$ by a microplate reader (model $\Sigma 960$ from Metertech).

\section{Results}

\section{Purification and Characterization of}

\section{Lebecetin}

Lebecetin was purified to homogeneity from the venom of $M$. lebetina in three steps: first by gel filtration chromatography, then by cation exchange chromatography and finally by RP-HPLC. Each fraction was assayed for inhibition of aggregation activity on rabbit whole blood. On SDS-PAGE (15\%), lebecetin behaved as a molecule of $29 \mathrm{kD}$ under nonreducing conditions and separated into bands of 15 and $16 \mathrm{kD}$ under reducing conditions. Lebecetin ( $5 \mathrm{nmol})$ was reduced, alkylated and separated into two peaks by RP-HPLC on a C8 column. MALDI TOF spectrometry data confirmed results obtained by SDSPAGE analysis and in particular the heterodimeric nature of lebecetin. The N-terminal amino acid sequence of both chains was determined and aligned with those of other members of C-type lectin-like protein from snake venom. $\alpha$ - and $\beta$-Subunits show $42 \%$ identity between them and respectively $28-67 \%$ [13, 14] and 40-55\% [14, 15] identity with those of the other corresponding $\alpha$ and $\beta$ CLP-related sequences.

\section{Effect of Lebecetin on Platelet Aggregation}

Lebecetin showed a potent inhibitory effect on platelet aggregation in rabbit whole blood induced by ADP $(1 \mathrm{mM})$ and $\mathrm{Ca}^{2+}$ - ionophore $\left(10^{-3} \mathrm{~m} M\right)$ with an $\mathrm{IC}_{50}$ of about $4 \mathrm{n} M$. This CLP was also able to inhibit rabbit and human washed platelet aggregation induced by thrombin $(0.04 \mathrm{IU} / \mathrm{ml})$. The $\mathrm{IC}_{50}$ was about $0.1 \mathrm{n} M$. Individually, both $\alpha$ - and $\beta$-subunits exhibited a distinct strong inhibitory effect. These results may suggest that individual lebecetin subunits contained interaction sites that enable them to bind to platelets.

Lebecetin inhibited both the aggregation of platelet-rich plasma induced by the antibiotic ristocetin and the agglutination of fixed platelets induced by bovine vWF in a dose-dependent manner. The concentration of lebecetin required for $50 \%$ inhibition of agglutination of the fixed platelets was approximately $0.5 \mathrm{n} M$. EDTA and EGTA significantly reduced the agglutination inhibiting activity of lebecetin. These results suggest the importance of $\mathrm{Ca}^{2+}$ for the expression of lebecetin activity.

\section{Effect of Lebecetin on Cancerous Adhesion Cells}

The inhibitory effect of lebecetin on the adhesion of cancerous cells to immobilized ECM (e.g., fibrinogen, collagen I and IV, laminin and vitronectin) was tested. Lebecetin potently inhibited the adhesion of HT29D4 cells (derived from adenocarcinoma) to laminin matrix as well as the adhesion of IGR39 melanoma cells to fibrinogen matrix. Moreover IGR39 cells and HT29D4 cells adhered tightly to immobilized lebecetin. The adhesion of lebecetin to IGR39 cells was dosedependent with an $\mathrm{ED}_{50}$ of $30 \mu \mathrm{g} / \mathrm{ml}$.

\section{Discussion}

Crude $M$. lebetina venom prevents platelet aggregation induced by collagen, thrombin or PAF acether with similar $\mathrm{IC}_{50}$ around $100 \mu \mathrm{g} / \mathrm{ml}$ [16]. Based on this observation, we isolated and described a potent inhibitor of platelet aggregation and agglutination named lebecetin. It is composed of two covalently linked subunits. Lebecetin has a high level of 
homology with N-terminal amino acid sequences of CLPs. Thus lebecetin belongs to the CLP class of snake venom proteins.

Lebecetin inhibits platelet aggregation induced by different agonists such as ADP, $\mathrm{Ca}^{2+}$-ionophore and thrombin. It is also able to inhibit PRP and washed fixed platelets in the presence of ristocetin. On the other hand, we found that lebecetin predominantly inhibits adhesion of HT29D4 to immobilized laminin and IGR39 to immobilized fibrinogen.
Work is in progress to determine the integrins on the surface of these cells interacting with lebecetin.

\section{Acknowledgements}

The authors recognize the friendly efforts of Dr. Cassian Bon from I. P. P. They also thank Prof. K. Dellagi for his support during this study.

\section{References}

1 Goldsteîn IJ, Hayer CE: The lectins: carbohydrate-binding proteins of plants and animals. Adv Carbohydr Chem Biochem 1978;35:127-131.

2 Devi A: The protein and nonprotein constituents of snake venom; in $\mathrm{Bu}-$ cherl W, Buckley E, Deulofeu V (eds): Venomous Animals and Their Venom. New York, Academic Press, 1968, pp 129-131.

3 Gartner TK, Oglive ML: Isolation and characterization of three $\mathrm{Ca}^{2+}$ dependent $\beta$-galactoside specific lectins from snake venom. Biochem $\mathbf{J}$ 1984;24:301-307.

4 Aragon-Ortiz F, Brenes-Brenes JR, Gubensek F: Characterization of a lectin-like protein isolated from $\mathrm{La}$ chesis muta snake venom. Rev Biol Trop 1989;37:79-84.

5 Fujimura Y, Titani K, Usami Y, Suzuki M, Oyama R, Matsui T, Fukui $\mathrm{H}$, Sugimoto $\mathrm{M}$, Ruggeri ZM: Isolation and characterization of two structurally and functionally distinct from botrocetin, the platelet coagglutinin from the venom of $\mathrm{Bo}$ throps jararaca. Biochemistry 1991; 30:1957-1964.

6 Peng M, Lu W, Kirby EP: Alboaggregins-B: A new platelet agonist that binds to platelet membrane glycoprotein Ib. Biochemistry 1991;30: 11529-11536.
7 Peng M, Lu W, Kirby EP: Characterization of three alboaggregins purified from Trimeresurus albolabris venom. Thromb Haemost 1992;67: 702-707.

8 Peng M, Lu W, Beviglia L, Niewiarowski S, Kirby EP: A snake venom protein that inhibits binding of von Willebrand Factor and alboaggregins to platelet glycoprotein $\mathrm{Ib}$. Blood 1993;81:2321-2328.

9 Chen YL, Tsai IH: Functional and sequence characterization of agkicetin, a new glycoprotein Ib antagonist isolated from Agkistrodon acutus venom. Biochem Biophys Res Commun 1995;210:472-477.

10 De Marco L, Girolami A, Zimmerman TS, Ruggeri ZM: Von Willebrand factor interaction with the glycoprotein IIb/IIa complex. Its role in platelet function as demonstrated in patients with congenital afibrinogenemia. J Clin Invest 1986; 77:1272-1277.

11 Ardlie NG, Packman MA, Mustard JF: Adenosine diphosphate induced platelet aggregation in suspensions of washed rabbit platelets. Br J Haematol 1970;19:7-17.

12 Kirby EP, Mills DCB: The interaction of bovine factor VIII with human platelets. J Clin Invest 1975;56: 491-502.
13 Taniuchi Y, Kawasaki T, Fujimura Y, Suzuki M, Titani K, Sakai K, Kaku S, Hisamichi N, Satoh V, Takenaka T, Handa M, Swai Y: Flavocetin-A and -B, two high molecular mass glycoprotein Ib binding proteins with high affinity purified from Trimeresurus flavoridis venom, inhibit platelet aggregation at high shear stress. Biochem Biophys Acta 1995;1244:331-338.

14 Cheng X, Qian Y, Liu Q, Li BX, Zhang M, Li J: Purification, characterization, and cDNA cloning of a new fibrinogenolytic venom protein, agkisacutacin, from Agkistrodon acutus venom. Biochem Biophys Res Commun 1999;265:530535.

15 Kawasaki T, Taniuchi Y, Hisamichi N, Fujimura Y, Suzuki M, Titani K, Kaku S, Satoh N, Takenaka T, Handa M, Swai Y: Tokaracetin, a new platelet antagonist that binds to platelet glycoprotein Ib and inhibits von Willebrand factor-dependent shear-induced platelet aggregation. Biochem J 1995;308:947-953.

16 Barbouche R, Marrakchi N, Mansuelle P, Krifi M, Fenouillet E, Rochat H, El Ayeb M: Novel anti-platelet aggregation polypeptides from Vipera lebetina venom: Isolation and characterization. FEBS Lett 1996;392:6-10. 